\title{
PENGARUH NET PROFIT MARGIN, DEBT TO EQUITY RATIO DAN EARNING PER SHARE TERHADAP RETURN SAHAM
}

\author{
Moh. Yudi Mahadianto, Siti Nur Hadiyati, dan Astri Harfiandita \\ Universitas Swadaya Gunung Jati Cirebon \\ Email:moh.yudim33@gmail.com, sitinurhadiyati@gmail.com,dan \\ harfiandita98@gmail.com
}

\begin{abstract}
The study aims to examine the effect of Net Profit Margin, Debt to Equity Ratio and Earning Per Share on stock returns in consumer goods industry sector companies listed in Indonesia Stock Exchange (IDX) period 2014-2018. The type of research used is basic research using quantitative methods. The population in this study consumer goods industry sector companies amounted to 51 companies listed in Indonesia Stock Exchange (IDX). The sampling selection used purposive sampling technique, the sample are 115 samples. Statistical methods this study used to descriptive statistical analysis, the classic assumption in the from of normality test, multicolinearity test, heteroscedaticity test and autocorrelation test, multiple regression analysis, coefficient of determination test $\left(R^{2}\right)$ and hypothesis testing conducted with $t$ (partial). The result of this study indicate that EPS has an effect on stock returns, while NPM and DER do not effect stock returns on the consumption sector companies listed in Indonesia Stock Exchange (IDX) period 2014-2018.
\end{abstract}

Keywords: Net Profit Margin, Debt to Equity Ratio, Earning Per Share, and Stock Returns.

\begin{abstract}
Abstrak
Penelitian ini bertujuan untuk menguji pengaruh Net Profit Margin, Debt to equity Ratio dan Debt to Equity Ratio terhadap Return Saham pada Perusahaan Sektor Industri Barang Konsumsi yang Terdaftar di Bursa Efek Indonesia Periode 2014-2018. Jenis penelitian yang digunakan adalah penelitian dasar dengan menggunkan metode kuantitatif. Populasi dalam penelitian ini adalah perusahaan sektor industri barang konsumsi berjumlah 51 perusahaan yang terdaftar di Bursa Efek Indonesia. Pemilihan sampel menggunakan teknik purposive sampling, jumlah sampel penelitian ini berjumlah 115 sampel. Metode statistik yang digunakan adalah analisis statistik deskriptif, uji asumsi klasik berupa uji normalitas, uji multikolinearitas, uji heteroskedastisitas dan uji autokorelasi, analisis regresi berganda, uji koefisien determinasi $\left(R^{2}\right)$ serta pengujian hipotesis dilakukan dengan uji $t$ (parsial). Hasil penelitian ini menunjukkan bahwa EPS berpengaruh terhadap Return Saham sedangkan NPM dan DER tidak berpengaruh terhadap Return Saham pada Sektor Industri Barang Konsumsi yang terdaftar di Bursa Efek Indonesia (BEI) periode 2014-2018.
\end{abstract}

Kata Kunci: Net Profit Margin, Debt to Equity Ratio, Earning Per Share, dan Return Saham. 


\section{PENDAHULUAN}

Federal Reserve System yang dikenal dengan akronim The Fed yang dikenal secara luas bahkan lingkup internasional. The Fed merupakan salah satu organisasi perbankan di Amerika Serikat yang menetapkan semua kebijakan moneter Amerika Serikat seperti menaikkan atau menurunkan suku bunga, mencoba untuk mengendalikan inflasi dan memiliki dampak yang besar terhadap pembelian dan penjualan saham dan obligasi. Dalam sebuah penelitian internasional menjelaskan ringkasan return saham pada Tabel 1 membandingkan empat Negara yang terdapat di Asia. Dengan membandingkan empat Negara bisa menentukan perbedaan tingkat pengembalian yang akan diberikan ke investor disetiap Negara.

Harga saham yang melambat di Amerika Serikat memiliki daya prediksi yang signifikan untuk pengembalian saham yang non-Amerika Serikat. Akan tetapi pasar nonAS memiliki daya prediksi yang terbatas untuk pasar-pasar lain Rapach et al. (2013). Ketika kepemilikan domestik investor internasional menurun, ia memiliki kekayaan yang lebih rendah dan lebih mungkin menjual kepemilikan asingnya Goldstein \& Pauzner (2004).

Tabel 1.

\begin{tabular}{cccc}
\multirow{2}{*}{$\begin{array}{c}\text { Ringkasan Return Saham pada Empat } \\
\text { Negara di Asia } \\
\text { Countries }\end{array}$} & \multirow{3}{*}{$\begin{array}{c}\text { Stock Return } \\
\text { Month }\end{array}$} & \multicolumn{2}{c}{ Volatility } \\
\cline { 2 - 4 } & & VE & VP \\
\hline Indonesia & 1 & 0,15 & 0,85 \\
& 4 & 0,12 & 0,88 \\
& 8 & 0,13 & 0,87 \\
& 12 & 0,11 & 0,89 \\
\hline Korea & 1 & 0,19 & 0,81 \\
& 4 & 0,15 & 0,85 \\
& 8 & 0,20 & 0,80 \\
& 12 & 0,23 & 0,77 \\
\hline Philippines & 1 & 0,02 & 0,98 \\
& 4 & 0,17 & 0,83 \\
\cline { 2 - 4 } & 8 & 0,24 & 0,76 \\
& 12 & 0,26 & 0,74 \\
\hline Thailand & 1 & 0,22 & 0,78
\end{tabular}

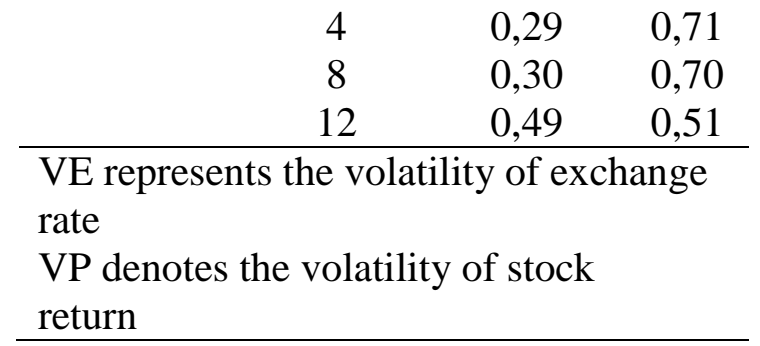

Sumber : Lim \& Sek (2014)

Pada penelitian Lim \& Sek (2014) hubungan antara ketidakstabilan nilai tukar dan pengembalian saham di empat Negara Asia yang mengalami fluktuasi karena adanya krisis keuangan tahun 1997. Dari tabel yang telah dijelaskan menunjukkan bahwa dampak yang sangat rendah dari ketidakstabilan nilai tukar terhadap besaran perubahan harga terdapat pada Negara Filipina dan Thailand. Dengan adanya ketidakstabilan dalam besaran perubahan harga menyebabkan return saham yang akan diberikan ke investor mengalami penurunan.

Pasar Modal berfungsi sebagai perantara (Intermediaries). Fungsi ini menghubungkan pertemuan antara pihak kelebihan dana (investor) dan pihak yang membutuhkan dana. Dengan adanya pasar modal pihak yang kelebihan dana (investor) dapat memilih untuk investasi yang memberikan return paling optimal. Dana yang di investasikan oleh investor akan dikelola untuk operasional perusahaan dengan secara produktif, sehingga investor akan mendapatkan return.

Secara umum masyarakat pemodal (investor) yang akan melakukan investasi, terlebih dahulu melakukan pengamatan dan penilaian terhadap perusahaan yang akan dipilih dengan memantau laporan keuangan perusahaan-perusahaan tersebut terutama perusahaan yang sudah go public. Return saham merupakan faktor yang memotivasi investor untuk berivestasi dan mendapatkan hasil imbalan atas keberanian investor menanggung risiko atas investasi yang dilakukannya. Ketika harga jual lebih tinggi dibandingkan harga beli maka harga saham akan meningkat, sehingga tingkat pengembalian yang diterima oleh investor 
mendapatkan keuntungan yang diharapkan. Berikut fenomena mengenai rata-rata return saham pada perusahaan sektor industri barang konsumsi yang listing di BEI pada tahun 2014-2018.

Tabel 2

Return Saham Sektor Industri Barang Konsumsi 2014-2018

\begin{tabular}{cccccc}
\hline Kode & \multicolumn{5}{c}{ Return saham } \\
\cline { 2 - 6 } Saham & $\mathbf{2 0 1 4}$ & $\mathbf{2 0 1 5}$ & $\mathbf{2 0 1 6}$ & $\mathbf{2 0 1 7}$ & $\mathbf{2 0 1 8}$ \\
\hline DLTA & 0,0263 & $-0,9864$ & $-0,0038$ & $-0,0300$ & 0,1983 \\
GGRM & 0,4643 & $-0,0511$ & 0,2091 & 0,3521 & $-0,0021$ \\
ICBP & $-0,8669$ & 0,0482 & $-0,3522$ & 0,0568 & 0,1807 \\
INAF & 1,3203 & $-0,5268$ & 26,8571 & 0,2607 & 0,1017 \\
INDF & 2,9153 & $-0,2084$ & 0,5768 & $-0,0079$ & $-0,0079$ \\
MLBI & $-0,9900$ & $-0,2923$ & 0,4900 & 0,2200 & 0,1735 \\
TCID & 0,5055 & $-0,0351$ & $-0,2176$ & 0,4320 & $-0,0363$ \\
UNVR & 0,3299 & 0,2641 & 0,0709 & 0,4643 & $-0,1805$ \\
\hline Sumber: Data sekunder yang diolah $(2020)$
\end{tabular}

Sumber: Data sekunder yang diolah (2020)

Berdasarkan data Tabel 2, terdapat 8 perusahaan dengan rata-rata return saham di setiap tahunnya mengalami fluktuasi. Hal ini terjadi karena harga pasar saham mengalami fluktuasi yang disebabkan karena permintaan terhadap saham perusahaan naik turun serta pada tahun 2018 indonesia mengalami peningkatan suku bunga sehingga para investor lebih memilih menabung di perbankan berupa tabungan dan deposito karena resikonya lebih rendah dibandingkan dengan menginvestasikan dananya di pasar modal.

Kinerja perusahaan merupakan nilai keberhasilan dari sebuah usaha yang dapat diukur dengan informasi keuangan maupun non keuangan. Harga saham merupakan cerminan dari return saham yang diperoleh. Artinya, return perusahaan sektor Barang Konsumsi cenderung mengalami penurunan. Return saham menurun terjadi karena pengaruh harga saham mengalami penurunan, disebabkan permintaan terhadap saham perusahaan menurun.

Dari kedua fenomena yang telah dijelaskan dapat disimpulkan bahwa return saham pada Negara Asia dan beberapa perusahaan sektor industri barang konsumsi yang terdapat di Indonesia mengalami fluktuasi hal ini disebabkan karena adanya kenaikan dan penurunan harga di pasar pada setiap tahunnya, dari ketidakstabilan tersebut dapat mempengaruhi return saham.

Banyak faktor yang mempengaruhi return saham diantaranya Net Profit Margin, Debt to Equity Ratio dan Earning Per Share. Net Profit Margin merupakan salah satu profitabilitas yang digunakan untuk memgukur keuntungan antara laba setelah bunga dan pajak dibandingkan dengan penjualan.

Semakin banyak penjualan yang dihasilkan maka semakin besar pula keuntungan yang didapat perusahaan. Sehingga perusahaan selalu memaksimalkan kinerja perusahaan agar Net Profit Margin selalu ditingkatkan karena semakin tinggi Net Profit Margin akan semakin efektifnya perusahaan untuk menghasilkan keuntungan yang diharapkan. Jika perusahaan memiliki nilai Net Profit Margin yang tinggi maka investor akan tertarik menanamkan modal pada perusahaan tersebut yang akan berpengaruh terhadap permintaan dan penawaran harga pasar saham. Semakin banyaknya permintaan akan mengakibatkan kenaikan pada harga saham sehingga dapat meningkatkan pula return saham perusahaan.

Faktor yang dapat mempengaruhi return saham selanjutnya adalah debt to equity ratio. Debt to Equity Ratio merupakan rasio perbandingan antara total utang 
perusahaan dengan total ekuitas perusahaan. DER yang menggambarkan sejauh mana modal perusahaan dapat menutupi utang kepada pihak kreditor.

Debt to Equity Ratio menunjukkan seberapa besar tingkat utang perusahaan terhadap modalnya. Semakin besar nilai Debt to Equity Ratio, maka dapat diartikan bahwa keuangan perusahaan sebagian besar sumber keuangan perusahaan akan semakin besar dibiayai oleh kreditor. Tentu dengan hal ini pertanda buruk bagi keuangan perusahaan. Begitupun sebaliknya jika perusahaan mampu membayar utang perusahaan dan rasio hutangnya rendah, besar kemungkinan tingkat pengembalian yang akan diberikan kepada pemegang saham pun sesuai yang diharapkan.

Selain Net Profit Margin dan Debt to Equity Ratio, Return saham juga dipengaruhi oleh Earning Per Share. Earning Per Share merupakan perbandingan antara laba bersih setelah pajak dengan jumlah lembar saham perusahaan. Earning Per Share merupakan laba perusahaan yang dibagikan untuk setiap lembar saham yang beredar dari saham biasa. Artiya tidak semua laba perusahaan dialokasikan untuk saham biasa, sebab jenis saham lain seperti saham preferen yang diterbitkan oleh perusahaan yang sama.

Semakin banyak jumlah saham beredar akan mempengaruhi tingkat atau besar laba per lembarnya. Sebab, keuntungan perusahaan akan dibagikan ke seluruh lembar saham yang diterbitkan oleh perusahaan. Ketika EPS meningkat, kesejahteraan pemegang saham akan meningkat dengan kata lain tingkat pengembalian yang tinggi. Tingkat pengembalian yang akan diberikan akan sesuai dengan yang diharapkan oleh pemegang saham.

Berdasarkan fenomena yang telah dijelaskan sebelumnya pada sektor industri barang konsumsi di Bursa Efek Indonesia mengalami fluktuasi serta hasil penelitian terdahulu yang tidak konsisten maka penelitian ini mengambil judul "Pengaruh Net Profit Margin, Debt to Equity Ratio dan Earning Per Share terhadap Return Saham
(Studi Empiris Pada Perusahaan Sektor Industri Barang Konsumsi yang Terdaftar di Bursa Efek Indonesia Periode 2014-2018)"

Berdasarkan uraian di atas, maka perumusan masalah dalam penelitian ini adalah (1) Apakah Net Profit Margin berpengaruh terhadap return saham (2) Apakah Debt to Equity Ratio berpengaruh terhadap return saham (3) Apakah Earning Per Share berpengaruh terhadap return saham.

\section{LITERATURE REVIEW}

Untuk memperluas referensi dan mendukung analisis maka diperlukan beberapa penelitian untuk menjadi referensi, beberapa penelitian tentang pengaruh Net Profit Margin, Debt to Equity Ratio dan Earning Per Share terhadap Return Saham sudah diteliti beberapa peneliti sebelumnya.

Berdasarkan penelitian terdahulu, terdapat beberapa perbedaan penelitian yang berkaitan dengan Net Profit Margin terhadap Return Saham. Pada Penelitian Nurlia \& Prameswary (2017), Setiani dkk. (2016) dalam hasil penelitiannya mengatakan bahwa Net Profit Margin berpengaruh terhadap return saham. Sedangkan Handayani (2019) dalam hasil penelitiannya mengatakan bahwa Net Profit Margin tidak berpengaruh terhadap return saham.

Menurut Y. Susilowati dkk. (2019), Murni dkk. (2015) menyimpulkan bahwa Debt to Equity Ratio berpengaruh terhadap Return Saham. Sedangkan penelitian menurut Hafni dkk. (2019), Darajat (2018) Debt to Equity Ratio tidak berpengaruh terhadap Return Saham.

Penelitian yang dilakukan oleh Handayati \& Zulyanti (2018), Gunadi \& Kesuma (2015) menyimpulkan bahwa Earning Per Share berpengaruh terhadap Return Saham. Sedangkan penelitian menurut Hakim \& Abbas (2017) Earning Per Share tidak berpengaruh terhadap Return Saham.

\section{METODE PENELITIAN}

Penelitian ini menggunakan jenis penelitian dasar (basic research). Penelitian dasar (basic 
research) adalah penelitian yang terutama dilakukan untuk meningkatkan pemahaman terhadap masalah tertentu yang kerap terjadi dalam konteks organisasi dan mencari metode untuk memecahkannya (Sekaran, 2016:9).

Oleh karena itu penelitian ini bertujuan untuk mengetahui pengaruh variabel independen terhadap variabel dependen dan seberapa kuat pengaruh tersebut. Berdasarkan jenis datanya, penelitian ini menggunakan data kuantitatif dengan menggunakan data berupa angka yang diperoleh dari website: $w w w . i d x$.co.id

Penelitian ini menggunakan metode kuantitatif. Metode penelitian kuantitatif dapat diartikan sebagai metode penelitian yang berlandaskan pada filsafat positivisme, digunakan untuk meneliti pada populasi dan sampel tertentu, pengumpulan data menggunakan instrumen penelitian, analisis data bersifat kuantitatif atau statistik, dengan tujuan untuk menguji hipotesis yang telah ditetapkan (Sugiyono, 2016:8). Dalam penelitian ini hubungan yang terjadi adalah Net Profit Margin (NPM), Debt to Equity Ratio (DER) dan Earning Per Share (EPS) terhadap return saham.

\section{Populasi dan Sampel}

Menurut Mahadianto, dkk (2017:11) menyatakan bahwa populasi adalah unit analisis yang memiliki karakteristik (ciri khas) yang membedakan dengan kumpulan lainnya dan tempat di mana data tersebut diukur. Dalam penelitian ini populasi yang digunakan yaitu perusahaan Sektor Industri Barang Konsumsi yang terdaftar di Bursa Efek Indonesia periode 2014-2018 yang berjumlah 51 Perusahaan.

Mahadianto dan Setiawan (2013:4) mengemukakan bahwa: "Sampel adalah bagian dari populasi yang diambil menurut teknik penarikan sampel yang tidak menghilangkan karakteristik yang melekat dalam kumpulan elemen". Pemilihan sampel dengan sampling purposive yang bertujuan untuk memperoleh sampel yang representative sesuai dengan kriteria yang telah ditentukan, adapun kriteria dalam pemilihan sampel pada penelitian ini meliputi:

1) Perusahaan Sektor Industri Barang Konsumsi yang terdaftar di Bursa Efek periode 2014-2018

2) Perusahaan Sektor Industri Barang Konsumsi yang listing pada periode 2014-2018

Adapun Pelanggaran kriteria meliputi:

1) Perusahaan Sektor Industri Barang Konsumsi yang listing pada periode penelitian

2) Perusahaan Sektor Industri Barang Konsumsi yang tidak memperoleh laba periode 2014-2018

Berdasarkan sampel diatas, perusahaan yang memenuhi kriteria terdiri dari 23 perusahaan. Penelitian ini dilakukan selama lima tahun dari 2014-2018. Sehingga jumlah keseluruhan sampel dalam penelitian ini sebanyak 115 sampel.

\section{Teknik Pengumpulan Data}

Data yang digunakan dalam penelitian ini adalah data sekunder, yang diperoleh dari dokumen-dokumen yang memuat data penelitian, yang disebut dengan teknik dokumentasi. Data penelitian diperoleh dari sumber sekunder (secondary data), seperti buku, publikasi pemerintah mengenai indikator ekonomi, media, laporan tahunan perusahaan dan lainnya situs Web, Internet, dan lainnya (Sekaran, 2016:55).

Data yang digunakan adalah data Ringkasan Kinerja Perusahaan dan Laporan Keuangan periode 2014-2018. Dari hasil penelitian ini akan dianalisa apakah ada pengaruh variabel independen yaitu Net Profit Margin, Debt to Equity Ratio dan Earning Per Share terhadap variabel dependen yaitu Return Saham.

\section{KONSEP DASAR}

\section{Pengaruh Net Profit Margin terhadap Return Saham}

Teori sinyal yang dikemukakan oleh Ross (1977) membahas mengenai dorongan perusahaan untuk memberikan informasi kepada pihak eksternal. Pihak manajemen 
dan pihak eksternal bisa menjadikan adanya dorongan asimetri informasi. Salah satu asimetri informasi yang diberikan perusahaan berupa laporan keuangan termasuk Net Profit Margin.

Net Profit Margin (NPM) disebut juga rasio pendapatan terhadap penjualan. Artinya NPM mengukur kemampuan perusahaan memperoleh laba bersihnya pada tingkat penjualan tertentu. NPM semakin meningkat menggambarkan kinerja perusahaan yang semakin baik dan menghasilkan keuntungan yang lebih meningkat pula. Hal ini dapat menarik investor untuk menanamkan modalnya sehingga harga saham meningkat dan berpengaruh terhadap kenaikan tingkat return saham. Namun, return saham bisa mengalami penurunan yang disebabkan adanya isu-isu atau berita negatif yang dapat mempengaruhi minat investor untuk menanamkan modalnya dan berdampak pada harga saham menurun sehingga return yang diberikan kepada investor mengalami penurunan.

Penelitian Nurlia dan Prameswary (2017) dan Setiani dkk. (2016) menunjukkan bahwa Net Profit Margin berpengaruh terhadap return saham. Berdasarkan landasan teori, kerangka pemikiran dan hasil penelitian yang telah diuraikan di atas, maka dapat dirumuskan hipotesis sebagai berikut:

$\mathrm{H}_{1}$ : Net Profit Margin berpengaruh terhadap Return Saham

\section{Pengaruh Debt to Equity Ratio terhadap Return Saham}

Teori sinyal yang dikemukakan oleh Ross (1977) membahas mengenai dorongan perusahaan untuk memberikan informasi kepada pihak eksternal. Pihak manajemen dan pihak eksternal bisa menjadikan adanya dorongan asimetri informasi. Salah satu asimetri informasi yang diberikan perusahaan berupa laporan keuangan termasuk Debt to Equity Ratio.

Debt to Equity Ratio (DER) adalah rasio total hutang dengan modal sendiri, merupakan perbandingan antara total hutang dengan modal sendiri (ekuitas). Debt to Equity Ratio akan mengakibatkan risiko keuangan perusahaan semakin meningkat. Dengan penggunaan hutang yang besar mengakibatkan semakin besar risiko perusahaan tidak mampu untuk membayar hutang. Biasanya investor menghindari risiko, maka semakin tinggi Debt to Equiy Ratio (DER) akan mengakibatkan perusahaan tersebut dihindari investor, sehingga harga saham semakin menurun.

Penelitian E. M. Susilowati \& Nawangsasi (2018) dan Handayati \& Zulyanti (2018) menunjukkan bahwa Debt to Equity Ratio berpengaruh terhadap return saham. Berdasarkan landasan teori, kerangka pemikiran dan hasil penelitian yang telah diuraikan di atas, maka dapat dirumuskan hipotesis sebagai berikut:

\section{$\mathrm{H}_{2}$ : Debt to Equity Ratio berpengaruh terhadap Return Saham}

\section{Pengaruh Earning Per Share terhadap Return Saham}

Teori sinyal yang dikemukakan oleh Ross (1977) membahas mengenai dorongan perusahaan untuk memberikan informasi kepada pihak eksternal. Pihak manajemen dan pihak eksternal bisa menjadikan adanya dorongan asimetri informasi. Salah satu asimetri informasi yang diberikan perusahaan berupa laporan keuangan termasuk Earning Per Share.

Earning Per Share (EPS) adalah keuntungan perusahaan yang biasa dibagikan kepada pemegang saham. Tetapi dalam praktiknya, tidak semua keutungan ini dapat dibagikan, ada sebagian yang ditahan sebagai laba ditahan. Semakin tinggi nilai Earning Per Share menunjukkan semakin besar laba yang diberikan untuk pemegang saham. Artinya, Earning Per Share yang tinggi merupakan daya tarik bagi investor yang akan menanamkan modalnya kedalam perusahaan, sehingga memberi dampak positif pada calon investor untuk meningkatkan kepemilikan saham pada perusahaan tersebut.

Penelitian Handayati \& Zulyanti (2018) dan Gunadi \& Kesuma (2015) 
menunjukkan bahwa Earning Per Share berpengaruh terhadap return saham. Berdasarkan landasan teori, kerangka pemikiran dan hasil penelitian yang telah diuraikan di atas, maka dapat dirumuskan hipotesis sebagai berikut :

\section{$\mathrm{H}_{3}$ : Earning Per Share berpengaruh terhadap Return Saham}

\section{PEMBAHASAN DAN DISKUSI}

\section{Hasil}

\section{Statistik Deskriptif}

Statistik deskriptif adalah gambaran atau deskripsi suatu data yang dilihat dari nilai rata-rata, maksimum, minimum, sum, range, deviasi standar, varian, kurtosis dan skewness (kemencengan distribusi). Pada penelitian ini statistik deskriptif digunakan untuk memberikan gambaran suatu data mengenai Net Profit Margin, Debt to Equity Ratio, Earning Per Share dan return saham perusahaan yang dilihat dari nilai minimum, maksimum, rata-rata dan standar deviasi untuk mengetahui apakah data yang diteliti berdistribusi normal. Berikut tabel statistik deskriptif dari masing-masing variabel dengan menggunakan SPSS 25:

Tabel 3

Statistik Deskriptif

\begin{tabular}{lrlrrr}
\hline & N & \multicolumn{1}{l}{ Min } & \multicolumn{1}{c}{ Max } & \multicolumn{1}{c}{ Mean } & \multicolumn{1}{c}{ Std. Deviation } \\
\hline NPM & 115 & 0,0089 & 1,9010 & 0,127068 & 0,1849627 \\
DER & 115 & 0,0607 & 3,0286 & 0,858747 & 0,6977732 \\
EPS & 115 & 0,2399 & 4050,2659 & 406,677267 & 801,9440817 \\
RS & 115 & $-0,9898$ & 2,9153 & 0,080315 & 0,5648421 \\
Valid N & 115 & & & & \\
(listwise) & & & & \\
\multicolumn{2}{l}{ Sumber: hasil output SPSS (2020) }
\end{tabular}

Berdasarkan tabel 3 statistik deskriptif menunjukkan jumlah sampel (n) sebanyak 115 sampel dari 23 perusahaan. Return saham paling rendah (minimum) dengan nilai $-0,9898$ dan nilai tertinggi (maximum) sebesar 2,9153. Nilai rata-rata (mean) return saham sebesar 0,080315 lebih kecil daripada nilai standar deviasi sebesar 0,5648421 . Artinya, return saham memiliki data yang tidak sama atau variatif.

Net Profit Margin memiliki nilai terendah (minimum) dengan nilai $\mathrm{Rp}$ 0,0089 dan nilai tertinggi (maximum) dengan nilai $\mathrm{Rp}$ 1,9010. Nilai rata-rata (mean) dengan nilai $\mathrm{Rp}$ 0,127068 lebih kecil daripada nilai standar deviasi dengan nilai Rp 0,1849627. Artinya, Net Profit Margin memiliki data yang tidak sama atau variatif.

Debt to Equity Ratio memiliki nilai terendah (minimum) dengan nilai 0,0607 dan nilai tertinggi (maximum) dengan nilai 3,0286 . Nilai rata-rata (mean) dengan nilai 0,858747 lebih kecil daripada nilai standar deviasi dengan nilai Rp 0,6977732. Artinya,
Debt to Equity Ratio memiliki data yang tidak sama atau variatif.

Earning Per Share memiliki nilai terendah (minimum) dengan nilai $\mathrm{Rp}$ 0,2399 dan nilai tertinggi (maximum) dengan nilai $\mathrm{Rp}$ 4050,2659. Nilai rata-rata (mean) dengan nilai Rp 406,677267 lebih kecil daripada standar deviasi dengan nilai Rp 801.9440817. Artinya, Earning Per Share memiliki data yang tidak sama atau variatif.

\section{Uji Asumsi Klasik}

Uji normalitas diperlukan karena untuk melakukan pengujian-pengujian variabel lainnya dengan mengasumsikan bahwa nilai residual mengikuti distribusi normal. Uji normalitas yang digunakan pada penelitian ini adalah One-Sample Kolmogorov-Smirnov Test, bila nilai signifikan residualnya lebih dari 0,05 (sig > 0,05) maka variabel tersebut telah berdistribusi normal. Berikut hasil pengolahan data dengan menggunakan SPSS 25: 
Tabel 4

Hasil Uji One-Sample Kolmogorov-Smirnov

\begin{tabular}{llr}
\hline & & $\begin{array}{c}\text { Unstandardized } \\
\text { Residual }\end{array}$ \\
\hline $\mathrm{N}$ & Mean & 115 \\
Normal & 0,0000000 \\
Parameters $^{\text {a,b }}$ & Std. & 3,75146292 \\
& Deviation & \\
Most Extreme & Absolute & 0,400 \\
Differences & Positive & 0,400 \\
& Negative & $-0,320$ \\
Test Statistic & & 0.400 \\
Asymp. Sig. (2-tailed) & $0,000^{c}$ \\
\hline Sumber: hasil output SPSS (2020)
\end{tabular}

Berdasarkan hasil uji One-Sample Kolmogorov-Smirnov menunjukkan bahwa nilai signifikansi $<0,05$ yaitu sebesar 0,000 yang menunjukkan bahwa data tidak berdistribusi normal sehingga Hipotesis ditolak. Oleh karena itu, variabel Return Saham, Net Profit Margin, Debt to Equity Ratio dan Earning Per Share dilakukan pengobatan dengan cara melakukan outlier. Berikut hasil uji One-Sample KolmogorovSmirnov yang sudah dilakukan outlier:

\section{Tabel 5}

Hasil Uji Normalitas yang Dilakukan Outlier

\begin{tabular}{llr}
\hline & & $\begin{array}{c}\text { Unstandardized } \\
\text { Residual }\end{array}$ \\
\hline $\mathrm{N}$ & Mean & 92 \\
Normal & 0,0000000 \\
Parameters $^{\mathrm{a}, \mathrm{b}}$ & Std. & 0,33903568 \\
& Deviation & \\
Most & Absolute & 0,079 \\
Extreme & Positive & 0,072 \\
Differences & Negative & $-0,079$ \\
Test Statistic & & 0,079 \\
Asymp. Sig. (2-tailed) & $0,200^{\mathrm{cd}}$ \\
\hline
\end{tabular}

Sumber: hasil output SPSS (2020)

Berdasarkan tabel 5 hasil uji OneSample Kolmogorov-Smirnov yang telah dilakukan outlier menunjukkan bahwa nilai signifikansi $>0,05$ yaitu sebesar 0,200 yang berarti data telah berdistribusi normal. Dengan melakukan outlier ini maka jumlah n dalam penelitian akan berubah, dimana pada sebelum dilakukan outlier sebesar 115 sampel dan setelah dilakukan outlier sebesar 92 sampel.

\section{Uji Multikolnearitas}

Uji multikolinearitas bertujuan untuk mengetahui apakah terjadi korelasi antara variabel-variabel independen yang diikut sertakan dalam pembentukan model . Model regresi yang baik seharusnya tidak terjadi korelasi antar variabel independen. Untuk mengetahui apakah tidak terdapat multikolinearitas dengan cara melihat nilai tolerance dan Variance Inflaction Factor (VIF) yang dihasilkan oleh variabel-variabel independen pada tabel coefficients di hasil output SPSS 25. Berikut adalah hasil uji multikolinearitas yang dilakukan dalam penelitian:

Tabel 6

Hasil Uji Multikolinearitas

\begin{tabular}{|c|c|c|c|}
\hline \multirow[b]{2}{*}{ Model } & & \multicolumn{2}{|c|}{ Collinearity Statistics } \\
\hline & & Tolerance & VIF \\
\hline 1 & (Constant) & & \\
\hline & NPM & 0,961 & 1,041 \\
\hline & DER & 0,954 & 1,049 \\
\hline & EPS & 0,944 & 1,059 \\
\hline
\end{tabular}

a. Dependent Variable: RS

Sumber: hasil output SPSS (2020)

\section{Berdasarkan}

hasil

uji

multikolinearitas pada tabel 6 menjelaskan bahwa nilai tolerance variabel NPM sebesar 0,961, DER sebesar 0,954 dan EPS sebesar 0,944 dimana variabel independen pada nilai tolerance lebih dari 0,10 . Hal ini menunjukkan bahwa tidak terjadi korelasi yang kuat antar variabel independen atau tidak terjadi multikolinearitas. Uji multikolinearitas dilihat juga dari nilai VIF, variabel NPM memiliki nilai VIF sebesar 1,041, DER sebesar 1,049 dan EPS sebesar 1,059 yang berarti bahwa nilai VIF setiap variabel kurang dari 10 dan tidak terjadi multikolinearitas.

\section{Uji Heteroskedastisitas}

Uji Heteroskedastisitas bertujuan untuk menguji terjadinya perbedaan variance dari nilai residual pada suatu periode pengamatan ke periode pengamatan lainnya. Uji heteroskedastisitas dalam penelitian ini menggunakan uji statistik glejser. Berikut 
adalah hasil uji heteroskedastisitas yang dilakukan dengan menggunakan SPSS 25.

Tabel 7

Hasil Uji Heteroskedastisitas - Uji Statistik Glejser

\begin{tabular}{llrr}
\multicolumn{2}{l}{ Model } & \multicolumn{1}{c}{$\mathrm{t}$} & \multicolumn{1}{l}{ Sig. } \\
\hline 1 & (Constant) & 5,103 & 0000 \\
& NPM & $-1,501$ & 0,137 \\
& DER & 0,535 & 0,594 \\
& EPS & 0,100 & 0,921 \\
\hline
\end{tabular}

a. Dependent Variable: ABRESID

Sumber: hasil output SPSS (2020)

Berdasarkan tabel 7 hasil uji heteroskedastisitas - uji statistik glejser menunjukkan bahwa nilai signifikansi pada NPM sebesar 0,137, DER sebesar 0,594 dan EPS sebesar 0,921. Pada variabel independen menunjukkan bahwa nilai signifikansi tiap variabelnya lebih dari 0,05 . Dengan demikian dapat disimpulkan bahwa model regresi ini terbebas dari heteroskedastisitas.

\section{Uji Autokorelasi}

Uji autokorelasi bertujuan untuk mengetahui apakah dalam suatu model regresi linier ada korelasi antara kesalahan pengganggu pada periode sekarang dengan periode sebelumnya. Pengujian ini menggunakan uji durbin watson yaitu dengan membandingkan nilai durbin watson hitung (d) dengan nilai durbin watson tabel, yaitu batas atas (dU) dan batas bawah (dL).

\section{Tabel 8}

\section{Hasil Uji Autokorelasi}

\begin{tabular}{lr}
\hline Model & \multicolumn{2}{c}{ Durbin-Watson } \\
\hline 1 & 1,864 \\
\hline \multicolumn{3}{l}{ Sumber: hasil output SPSS (2020) }
\end{tabular}

Berdasarkan tabel 8 hasil uji autokorelasi menunjukkan nilai durbinwatson sebesar 1,864. Untuk mengetahui tidak terdapat autokorelasi yaitu dengan membandingkan nilai tabel dengan menggunakan nilai signifikansi 5\% dimana jumlah sampel sebesar 92 sampel (n) dan jumlah variabel independen tiga $(\mathrm{k}=3)$, makadi tabel durbin watson akan didapat nilai sebagai berikut:

Tabel 9

Tes Durbin Watson

\begin{tabular}{ccc}
\hline \multicolumn{3}{c}{$\mathrm{k}=3$} \\
\hline $\mathrm{n}$ & $\mathrm{dL}$ & $\mathrm{dU}$ \\
\hline 92 & 1,5941 & 1,7285 \\
\hline Sumber: tabel $d w$ & &
\end{tabular}

Nilai tabel DW ini berisi tentang batas atas (dL) dan batas bawah (dU). Nilai batas atas (dU) sebesar 1,7285 dan nilai batas bawah (dL) sebesar 1,5941. Pengambilan keputusan ada tidaknya autokorelasi yaitu dengan cara $\mathrm{dU}<\mathrm{d}<4$-dU. Oleh karena nilai (DW) 1,864 lebih besar dari batas atas (dU) 1,7285 dan kurang dari 4-1,7285 (4-dU), maka dapat disimpulkan bahwa model regresi ini tidak terdapat autokorelasi positif atau negative dapat disimpulkan terbebas dari autokorelasi.

\section{Uji Koefisien Determinasi $\left(\mathbf{R}^{\mathbf{2}}\right)$}

Koefisien determinasi $\left(\mathrm{R}^{2}\right)$ digunakan untuk mengukur dalam seberapa jauh kemampuan sebuah model dalam menjelaskan variasi variable dependen. Hasil uji koefisien determinasi dapat dilihat pada tabel 10 :

Tabel 10

Hasil Uji Koefisien Determinasi

\begin{tabular}{lr}
\hline Model & Adjusted $R$ Square \\
\hline 1 & 0,028 \\
\hline a. Predictors: (Constant), EPS, DER, NPM \\
b. Dependent Variable: RS \\
\hline Sumber: hasil output SPSS (2020)
\end{tabular}

Berdasarkan tabel 10 hasil uji koefisien determinasi, nilai pada Adjusted $R$ Square sebesar 0,028 yang menunjukkan bahwa return saham dapat dijelaskan oleh variabel independen Net Profit Margin, Debt to Equity Ratio dan Earning Per Share sebesar 2,8\% dan sisanya 97,2\% dijelaskan oleh faktor lain. 


\section{Pengujian Hipotesis (Uji t)}

Pengujian hipotesis pada penelitian ini dengan menggunakan uji $\mathrm{t}$ (parsial). Pengujian ini untuk mengetahui signifikansi atau tidak pengaruh variabel independen berupa Net Profit Margin, Debt to Equity Ratio dan Earning Per Share terhadap variabel dependennya yaitu return saham. Hasil pengujian hipotesis dengan menggunakan uji t ini dapat dilihat pada tabel 11:

Tabel 11

Hasil Pengujian Hipotesis

\begin{tabular}{|c|c|c|c|c|}
\hline \multirow[b]{2}{*}{ Model } & \multicolumn{2}{|c|}{$\begin{array}{c}\text { Unstandardized } \\
\text { Coefficients }\end{array}$} & \multirow[b]{2}{*}{$\mathrm{T}$} & \multirow[b]{2}{*}{ Sig. } \\
\hline & $\mathrm{B}$ & Std. Error & & \\
\hline $1 \quad$ (Constant) & $-0,089$ & 0,081 & $-1,095$ & 0,276 \\
\hline NPM & 0,233 & 0,491 & 0,475 & 0,636 \\
\hline DER & 0,002 & 0,056 & 0,041 & 0,968 \\
\hline EPS & 0,0001 & 0,0001 & 2,172 & 0,033 \\
\hline $\begin{array}{l}\text { a. Dependent } \\
\text { Variable: RS }\end{array}$ & & & & \\
\hline
\end{tabular}

Berdasarkan tabel 11, maka diperoleh persamaan regresi berganda sebagai berikut:

RS = -0,089 + 0,233 NPM + 0,002 DER + 0,0001

Hasil yang diperoleh dari uji t menunjukkan bahwa hanya Earning Per Share yang berpengaruh terhadap Return Saham yang dilihat dari nilai signifikansi sebesar 0,033 lebih kecil dari 0,05 $(0,033<$ $0,05)$ sementara Net Profit Margin memiliki nilai signifikansi sebesar 0,636 lebih besar dari 0,05 (0,636 > 0,05) dan Earning Per Share memiliki nilai signifikansi sebesar 0,968 lebih besar dari $0,05(0,968>0,05)$ sehingga tidak berpengaruh terhadap Return Saham.

\section{Hasil}

\section{Pengaruh Net Profit Margin terhadap Return Saham}

Berdasarkan data penelitian yang dilihat dari pengujian hipotesis, variabel Net Profit Margin tidak memiliki pengaruh terhadap Return saham. Hasil pengujian secara parsial yang berupa uji t mengatakan bahwa $\mathrm{Net}$
Profit Margin tidak berpengaruh terhadap return saham.

Penelitian ini sejalan dengan hasil penelitian yang dilakukan oleh Handayani (2019) yang mengatakan bahwa Net Profit Margin tidak berpengaruh terhadap Return saham. Akan tetapi penelitian ini tidak konsisten dengan penelitian Nurlia dan Prameswary (2017), Setiani dkk. (2016) mengatakan bahwa Net Profit Margin berpengaruh terhadap Return saham.

Net Profit Margin tidak berpengaruh terhadap return saham dapat disebabkan karena penjualan yang diperoleh perusahaan dan biaya yang dikeluarkan, ketika penjualan perusahaan meningkat dengan biaya yang rendah belum tentu dapat mempengaruhi return saham menjadi tinggi. Begitupun sebaliknya, penjualan yang rendah dengan biaya yang tinggi belum tentu dapat mempengaruhi return saham menjadi rendah.

Berdasarkan data yang diperoleh dari laporan tahunan, mayoritas perusahaan sektor industri barang konsumsi yang terdaftar di Bursa Efek Indonesia periode 2014-2018 mengalami penurunan Net Profit Margin, penurunan Net Profit Margin yang terjadi menunjukkan penurunan yang signifikan sehingga hal ini berdampak terhadap return saham. Sesuai dengan teori sinyal, bahwa dengan terjadinya penurunan Net Profit Margin yang dimiliki perusahaan maka hal ini memberikan informasi berupa sinyal yang negatif bagi investor sehingga variabel $\mathrm{Net}$ Profit Margin tidak dapat dijadikan acuan untuk memprediksi return saham.

\section{Pengaruh Debt to Equity Ratio terhadap Return Saham}

Berdasarkan data penelitian yang dilihat dari pengujian hipotesis, variabel debt to equity ratio tidak memiliki pengaruh terhadap return saham. Hasil pengujian secara parsial yang berupa uji t mengatakan bahwa debt to equity ratio tidak berpengaruh terhadap return saham.

Penelitian ini sejalan dengan hasil penelitian yang dilakukan oleh Hafni dkk. (2019) dan Darajat (2018) mengatakan bahwa 
debt to equity ratio tidak berpengaruh terhadap return saham. Akan tetapi penelitian ini tidak konsisten dengan penelitian Y. Susilowati dkk. (2019) dan Murni dkk. (2015) yang menyatakan bahwa debt to equity ratio berpengaruh terhadap return saham.

Debt to Equity Ratio tidak berpengaruh terhadap return saham disebabkan karena adanya kenaikan utang pada perusahaan yaitu utang yang meningkat lebih tinggi dibandingkan modal sendiri. Perusahaan yang memiliki DER tinggi jika tidak bisa membayar utang kepada kreditor maka perusahaan dapat mengalami likuidasi. Sehingga perusahaan yang memiliki risiko keuangan yang tinggi cenderung dihindari oleh investor.

Berdasarkan data yang diperoleh dari laporan tahunan, mayoritas perusahaan sektor industri barang konsumsi yang terdaftar di Bursa Efek Indonesia periode 2014-2018 mengalami kenaikan debt to equity ratio, namun kenaikan debt to equity ratio yang terjadi menunjukkan kenaikan yang signifikan sehingga hal ini berdampak terhadap return saham. Sesuai dengan teori sinyal, bahwa dengan terjadinya kenaikan debt to equity ratio yang dimiliki perusahaan maka hal ini memberikan informasi berupa sinyal yang negatif bagi investor sehingga variabel debt to equity ratio tidak dapat dijadikan acuan untuk memprediksi return saham.

\section{Pengaruh Earning Per Share terhadap Return Saham}

Berdasarkan data penelitian yang dilihat dari pengujian hipotesis, variabel earning per share memiliki pengaruh terhadap return saham. Hasil pengujian secara parsial yang berupa uji t mengatakan bahwa earning per share berpengaruh terhadap return saham.

Penelitian ini sejalan dengan hasil penelitian yang dilakukan oleh Handayati \& Zulyanti (2018) dan Gunadi \& Kesuma (2015) yang menyatakan bahwa earning per share berpengaruh terhadap return saham. Akan tetapi penelitian ini tidak konsisten dengan penelitian Hakim \& Abbas (2017) mengatakan bahwa earning per share tidak berpengaruh terhadap return saham.

Earning Per Share berpengaruh terhadap return saham dikarenakan adanya laba bersih yang diperoleh perusahaan dibandingkan dengan jumlah saham yang beredar. Apabila laba bersih perusahaan tinggi dengan jumlah saham yang beredar rendah, maka akan meningkatkan keuntungan per lembar saham yang diterima investor yang kemudian dapat mempengaruhi harga saham menjadi tinggi. Ketika harga saham tinggi maka akan berpengaruh pula pada kenaikan return saham. Sehingga menyebabkan investor memburu suatu saham akibatnya return saham perusahaan meningkat.

Berdasarkan data yang diperoleh dari laporan tahunan, mayoritas perusahaan sektor industri barang konsumsi yang terdaftar di Bursa Efek Indonesia periode 2014-2018 mengalami kenaikan earning per share. Kenaikan earning per share sesuai dengan teori sinyal, dengan terjadinya kenaikan earning per share yang dimiliki perusahaan sehingga memberikan informasi berupa sinyal yang positif bagi investor serta variabel earning per share dapat dijadikan acuan untuk memprediksi return saham.

\section{KESIMPULAN}

Berdasarkan hasil pembahasan di atas, maka dapat disimpulkan sebagai berikut:

1. Hasil pengujian hipotesis mengenai pengaruh Net Profit Margin terhadap return saham menunjukkan bahwa net profit margin tidak berpengaruh terhadap return saham. Karena penjualan yang diperoleh perusahaan dan biaya yang dikeluarkan, ketika penjualan perusahaan meningkat dengan biaya yang rendah belum tentu dapat mempengaruhi return saham menjadi tinggi. Penurunan ini kemungkinan disebabkan manajemen dalam perusahaan tersebut tidak mampu menekan biaya-biaya sehingga menghasilkan laba yang rendah atas penjualan dengan demikian dapat 
mendorong investor untuk tidak berinvestasi. Namun beberapa investor tidak memperhatikan net profit margin sebagai rasio yang dapat dipertimbangkan dalam keputusan investasi.

2. Hasil pengujian hipotesis mengenai pengaruh Debt to Equity Ratio terhadap return saham menunjukkan bahwa debt to equity ratio tidak berpengaruh terhadap return saham. Karena adanya kenaikan utang pada perusahaan yaitu utang yang meningkat lebih tinggi dibandingkan modal sendiri. Perusahaan yang memiliki DER tinggi jika tidak bisa membayar utang kepada kreditor maka perusahaan dapat mengalami likuidasi. Sehingga perusahaan yang memiliki risiko keuangan yang tinggi cenderung dihindari oleh investor.

3. Hasil pengujian hipotesis mengenai pengaruh Earning Per Share terhadap return saham menunjukkan bahwa earning per share berpengaruh terhadap return saham. Dikarenakan adanya laba bersih yang diperoleh perusahaan dibandingkan dengan jumlah saham yang beredar. Apabila laba bersih perusahaan tinggi dengan jumlah saham yang beredar rendah, maka akan meningkatkan keuntungan per lembar saham yang diterima investor yang kemudian dapat mempengaruhi harga saham menjadi tinggi. Ketika harga saham tinggi maka akan berpengaruh pula pada kenaikan return saham. Sehingga menyebabkan investor memburu suatu saham akibatnya return saham perusahaan meningkat.

\section{DAFTAR PUSTAKA}

Ayem, \& Astuti. (2019). Pengaruh Earning Per Shares (EPS), Leverage, Ukuran Perusahaan Dan Tax Planning Terhadap Return Saham Perusahaan. Jurnal Akuntansi Dewantara, 3(2), 2.

Brigham, E. F., \& Houston, J. F. (2011). Dasar-dasar Manajemen Keuangan (11th ed.). Salemba Empat.
Cheng, S., Nagar, V., \& Rajan, M. V. (2007). Insider trades and private information: The special case of delayed-disclosure trades. Review of Financial Studies, 20(6), 1833-1864. https://doi.org/10.1093/rfs/hhm029

Darajat, Z. (2018). Pengaruh ROA, ROE , EPS dan DER terhadap Return Saham. Journal of Chemical Information and Modeling, 53(9), 1689-1699.

https://doi.org/10.1017/CBO9781107 415324.004

Fahmi. (2014). Manajemen keuangan perusahaan dan pasar modal (Pertama). Mitra wacana media.

Ghozali, I. (2018). Aplikasi Analisis Multivariate dengan Program IBM SPSS 25 (9th ed.). Badan Penerbit Universitas Diponogoro.

Gill, james o., \& Chatton, M. (2006). Memahami Laporan Keuangan. Victory Jaya Abadi.

Goldstein, I., \& Pauzner, A. (2004). Contagion of Self-fulfilling Financial Crises Due to Diversification of Investment Portfolios. Journal of Economic, 119, 151-183.

Gunadi, G., \& Kesuma, K. (2015). Pengaruh Roa, Der, Eps Terhadap Return Saham Perusahaan Food and Beverage Bei. E-Jurnal Manajemen Universitas Udayana, 4(6), 16361647.

Hafni, L., Sarisa, \& Safari, S. (2019). Analysis of Influence of Current Ratio (Cr), Debt To Equity Ratio (Der), Return on Equity(Roe), and Earning Per Share (Eps) on Stockreturn Lq45 Listed on Indonesian Stock Exchange Period 2012-2016. Bilancia, Jurnal Ilmiah Akuntansi, 3(3), 324-334.

Hakim, M. Z., \& Abbas, D. S. (2017). Pengaruh Price Earning Ratio, Earning Per Share, Return On Equity, Debt to Equity Ratio dan Net Profit Margin terhadap Return Saham (Pada Sektor Property and Real Estate Yang Terdaftar Di Bursa Efek Indonesia 
Periode 2013-2017) 1)Mohamad. World Agriculture. https://doi.org/10.1038/132817a0

Handayati, R., \& Zulyanti, N. R. (2018). Pengaruh Earning Per Share (Eps), Debt To Equity Ratio, (Der), Dan Return on Assets (Roa) Terhadap Return Saham Pada Perusahaan Manufaktur Yang Terdaftar Di Bei. Jurnal Manajemen, 3(1), 615. https://doi.org/10.30736/jpim.v3i1.1 43

Harahap, S. S. (2013). Analisis Kritis Atas Laporan Keuangan (Edisi 11). Rajawali Pers.

Hartono, J. (2017). Teori Portofolio dan Analisis Investasi (Edisi Kesebelas). BPPE, Yogyakarta.

Hermawan, D. A. (2012). Pengaruh Debt To Equity Ratio, Earning Per Share Dan Net Profit Margin Terhadap Return Saham. Management Analysis Journal, $\quad 1(1), \quad 1-7$. https://doi.org/10.15294/maj.v1i1.49 8

Indra Widjaja, I. T. S. D. (2019). Pengaruh Earning Per Share, Debt To Equity Ratio, Price Earning Ratio, Return On Equity Terhadap Harga Saham Perusahaan Makanan Dan Minuman Di Bei Periode 2015-2017. Jurnal Manajemen Bisnis Dan Kewirausahaan, 3(2), 24-33. https://doi.org/10.24912/jmbk.v3i2.4 956

Jogiyanto. (2009). Teori Portofolio dan Analisis Investasi. BPPE-UGM.

Jumingan. (2014). Analisis Laporan Keuangan. Media Grafika.

Kasmir. (2013). Analisis Laporan Keuangan. PT. Rajagrafindo Persada.

Kidder, L. (1981). Research Methods in Social Relation. Holt, Rinehart and Winston.

Lim, S. Y., \& Sek, S. K. (2014). Exploring the Inter-relationship between the Volatilities of Exchange Rate and Stock Return. Procedia Economics and Finance, 14(14), 367-376. https://doi.org/10.1016/s2212-

5671(14)00725-4

Maditinos, D. I., Theriou, N. G., \& Šević, Z. (2009). Modelling traditional accounting and modern value/based performance measures to explain stock market returns in the Athens Stock Exchange (ASE). Journal of Modelling in Management, 4(3), 182201.

https://doi.org/10.1108/17465660911 006431

Mahadianto, Y., Setiawan, A., Solahudin, Adi., \& Ernawati, S (2017). Pengantar Statistik 1 (D. Murti (ed.)). PT. Penerbit IPB Press.

Mahadianto, Y., \& Setiawan, A. (2013). Analisis Parametrik Dependensi dengan Program SPSS untuk Pengolahan Data Tugas Akhir. PT. Rajagrafindo Persada.

Markowitz, H. (1952). portofolio selection. Jurnal of Finance.

Melisa Handayani, I. H. (2019). Analysis Of Effect Of Debt To Equity Ratio (DER), Return On Asset (ROA), Return On Equity (ROE), and Net Profit Margin (NPM) On Stock Return (Case Study On Consummer Goods Companies In Indonesia Stock EXCHANGE). Jurnal Ilmiah Manajemen, 13(7), 1-11.

Murni, S., Basalama, I. S., \& Sumarauw, J. S. B. (2015). Pengaruh Current Ratio, DER dan ROA terhadap Return Saham pada Perusahaan Automotif dan Komponen Periode 2013-2015. The Journal of the Japan Society for Respiratory Endoscopy, 37(3), 343. https://doi.org/10.18907/jjsre.37.3_34 3_4

Nanda, S., \& Panda, A. K. (2018). The determinants of corporate profitability: an investigation of Indian manufacturing firms. International Journal of Emerging Markets, 13(1), 66-86. https://doi.org/10.1108/IJoEM-012017-0013 
Nurlia, \& Prameswary, V. A. (2017). Pengaruh Net Profit Margin (NPM), Return On Equity (ROE), Earning Per Share (EPS) dan Price Earning Ratio (PER) terhadap Return Saham pada Perusahaan Farmasi yang terdaftar di Bursa Efek Indonesia. Journal Geo Ekonomi, 60-74.

Nurmasari, I. (2018). Pengaruh Rasio Keuangan Dan Pertumbuhan Pendapatan Terhadap Return Saham Pada Perusahaan Perkebunan Di Bursa Efek Indonesia 2010-2017. Jurnal SEKURITAS (Saham, Ekonomi, Keuangan Dan Investasi), 2(1).https://doi.org/10.32493/skt.v2i 1.1959

Obreja, I. (2013). Book-to-market equity, financial leverage, and the crosssection of stock returns. Review of Financial Studies, 26(5), 1146-1189. https://doi.org/10.1093/rfs/hhs 180

Priyastama, R. (2017). Buku Sakti Kuasai SPSS Pengolahan Data \& Analisis Data. Start Up.

Rapach, D. E., Strauss, J. K., \& Zhou, G. (2013). International stock return predictability: What is the role of the united states? Journal of Finance, 68(4), 1633-1662. https://doi.org/10.1111/jofi.12041

Ross, S. A. (1977). The Determination of Financial Structure: The Incentive Signalling Approach. The Bell Journal of Economics, 8(1), 1-21.

Sarifudin, A., \& Manaf, S. (2016). Pengaruh Arus Kas Operasi, Arus Kas Investasi, Arus Kas Pendanaan dan Laba Bersih Terhadap Return Saham pada Perusahaan Manufaktur yang Terdaftar di Bursa Efek Indonesia. Dharma Ekonomi, 43, 1-12.

Sekaran, U. (2016). Research Methods For Bussiness (4th ed.). Salemba Empat.

Setiani, T., Maryana, D., \& Elisabeth, C. R. (2016). Pengaruh Net Profit Margin (NPM), Return On Assets (ROA), Earning Per Share (EPS) dan Price Earning Ratio (PER) terhadap
Return Saham ( Suatu Penelitian Pada Saham LQ45 di Bursa Efek Indonesia Periode Januari 2014 Sampai Dengan Juni 2015 ) ISSN : 11(2), 33-43.

Sugiyono. (2011). Metode Penelitian Administrasi dilengkapi dengan Metode $R \& D$. Alfabeta.

Sugiyono. (2016). Metode Penelitian Kuantitatif, Kualitatif dan $R \& D$. Alfabeta.

Susilowati, E. M., \& Nawangsasi, E. (2018). Pengaruh Current Ratio, Debt To Equity, Price Earning Ratio, Total Assets Turn Over Terhadap Return Saham LQ45. ProBank: Jurnal Ekonomi Dan Perbankan, 3(2), 4351.

Susilowati, Y., Basukianto, Aini, N., \& Alifani, A. J. (2019). Analisis Fundamental terhadap Return Saham (Perusahaan Manufaktur Yang Terdaftar Pada Bursa Efek Indonesia Tahun 2014-2018). Berputas, 3(9), 88-99.

Syamni, G., Wahyuddin, Damanhur, \& Ichsan. (2018). CSR and Profitability in IDX Agricultural Subsectors. 1, 511-517. https://doi.org/10.1108/978-1-78756793-1-00034

Tandellin. (2010). analisis investasi dan manajemen portofolio (Edisi Pert). Bpfe.

Warwati, S. simanjuntak, Sipayung, H., Sinaga, A. N., Permana, J., \& Hutahaen, T. F. (2019). Pengaruh Struktur Modal, Net Profit Margin, Current Ratio, dan Price Earning Ratio terhadap Return Saham pada perusahaan manufaktur sektor industri barang konsumsi yang terdaftar di Bursa Efek Indonesia periode 20142017. Akrab Juara.

Zubir, Z. (2011). Manajemen Portofolio Penerapannya Dalam Investasi Saham. Salemba Empat.

www.idx.co.id www.sahamOK.com 